\title{
A formação do artista circense: relatos de experiência do Coletivo O Circo Tá na Rua
}

Mesa Temática: Pedagogia da Cena e Formação do Artista

\section{Resumo}

A formação do artista circense a partir de relatos de experiência com o "Coletivo O Circo Tá na Rua”. Objetiva-se observar aspectos das relações da ocupação artística de espaços públicos com a formação de artistas circenses. Permeiam esta análise a evolução histórica da pedagogia circense, subsidiada por conceitos de construção das identidades dos sujeitos galgadas na coletividade, a partir da (re)construção de uma noção de espaço enquanto condição de possibilidade de compartilhamento de ideais e bem simbólicos comuns. Trata-se de um estudo qualitativo de caráter descritivo que utiliza-se da observação participante como instrumentos de pesquisa e relatos de experiência para obtenção dos resultados. Observou-se correlação direta das atividades desenvolvidas pelo coletivo com os conceitos de identidade, espaço e suas relações, bem como o resultado positivo da proposta de ensino-aprendizagem em uso, resultando na eficácia do aprendizado das técnicas circenses.

Palavras-chave: Formação do artista circense. Ocupação artística. Espaço público. O Circo Tá na Rua. Relato de Experiência.

\begin{abstract}
The formation of the circus artist based on experience reports with the "Coletivo O Circo Tá na Rua. It aims to observe aspects of the relations of the artistic occupation of public spaces with the formation of circus artists. This analysis uses the historical evolution of circus pedagogy, subsidized by concepts of the construction of the identities of individuals in the collective, starting from the (re)construction space's notion as a condition of possibility of sharing common ideals and symbolic good. It is a qualitative study of a descriptive character that uses participant observation as research tools and experience reports to obtain the results. It was observed a direct correlation of the activities developed by the collective with the concepts of identity, space and their relations, as well as the positive result of the teachinglearning proposal in use, resulting in the effective learning of circus techniques.
\end{abstract}

Palavras-chave: Circus artist’s building. Artistic occupation. Public space. O Circo Tá na Rua. Experience Report.

Historicamente, Duprat (2014) traça a paulatina transformação que ocorre na formação do artista circense. Aquela que outrora dava-se pela tradição oral, no seio da família e atrelado à formação cidadã do indivíduo, sofre o impacto da modernidade, mais precisamente no final da década de 1970, e amplia-se mediante modos de formação profissional, através do surgimento de escolas especializadas e da inserção de novas pessoas interessadas em estudar/pesquisar circo. 
As primeiras escolas de circo foram: Academia Piolin de Artes Circenses (1977), Circo Escola Picadeiro (1984) e Escola Nacional de Circo (1982). Desde então surgiram várias outras com formato e intuitos semelhantes: formar artistas circenses com diversas habilidades e, para além da técnica, suscitar nos jovens sentimentos de solidariedade, respeito e cooperação (FIGUEIREDO, 2007).

Em retrospecto, histórico e conceitualmente, Resende (1975, p. 23) trata da formação do artista "a partir de um conceito preciso de seu papel na sociedade. Tal conceituação implica discutir o espaço ocupado, [...] e, mais, implica verificar a relação, decorrente, entre o processo formativo do artista e sua real possibilidade de atuação”.

O pensamento do autor remete-nos ao conceito de identidade trazido por Woodward (2005), no qual a construção do sujeito parte de suas relações sociais e do universo simbólico que ele compartilha. Em medida, isso dá-se em um espaço público comum que, como coloca Garcia (2017), mediante reconfigurações e ressignificações oriundas dessa identidade coletiva, resultam na construção de signos de bem-estar e satisfação.

Tais conceitos são facilmente observáveis no objeto desta pesquisa. O Coletivo O Circo Tá na Rua (Figura 01) intitula-se uma ocupação artística da Praça Nauro Machado no Centro histórico de São Luís, mediante treinos de circo semanais (segundas-feiras) gratuitos e públicos para a população. Trata-se de uma oficina aberta a todos (Figura 02) e sem a figura de um professor, em um processo de ensino-aprendizagem de múltiplos papéis, onde todos podem aprender e ensinar.

Do ponto de vista metodológico, trata-se de um estudo descritivo, de caráter qualitativo, haja vista que essa abordagem possibilita analisar características que não permitem a operacionalização de variáveis, pois trata-se de relações e fenômenos de maneira mais profunda, aos moldes propostos por Minayo (2010). Para tanto, utilizou-se o instrumento da observação participante que resultou em relatos de experiência dos pesquisadores. 
Figura 01: Coletivo O Circo Tá na Rua

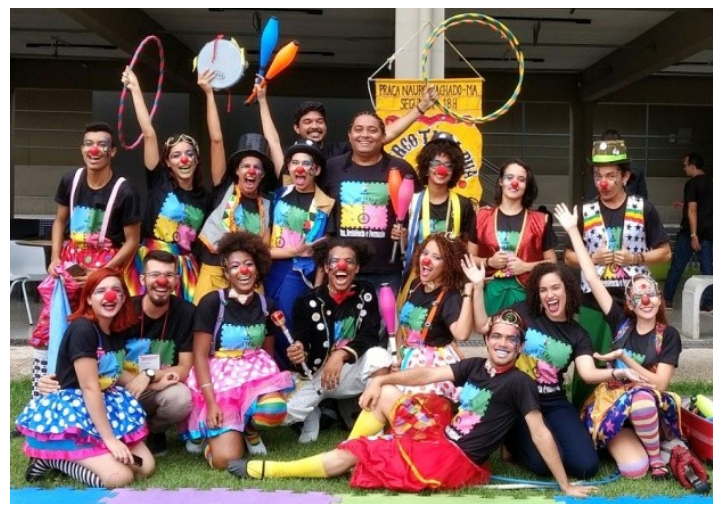

Fonte: Arquivo Pessoal
Figura 02: Treino de circo aberto e gratuito

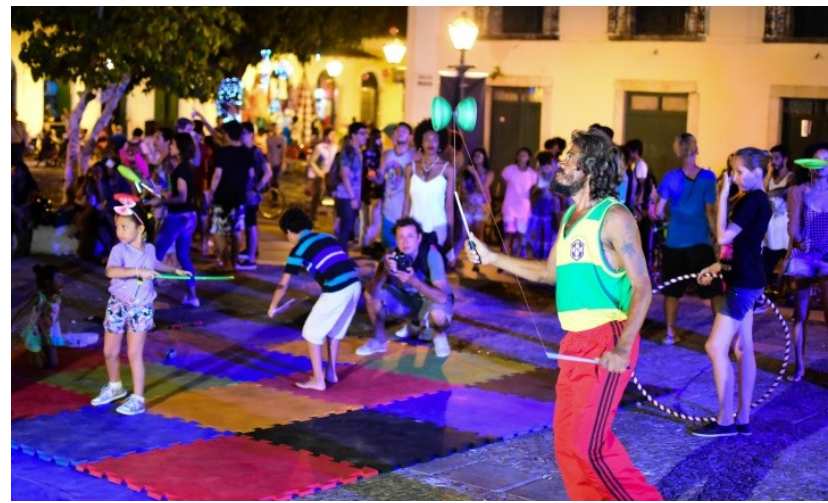

Fonte: Arquivo Pessoal; Foto de Fausto Ricardo.

De imediato nota-se a ausência de um professor ou pessoa que “conduza” as atividades. É possível identificar alguns integrantes do grupo a partir de suas camisas com a estampa do coletivo, mas não são somente eles que ensinam as técnicas. Embora Aguiar e Carrieri (2016) apontem que o circense é "aquele que aprende com seus pares [...] aquele com quem ele partilha os mesmos códigos simbólicos, os circenses.”, referindo-se às famílias tradicionais, vê-se que em circos sociais a perspectiva é completamente oposta. Todos aprendem e ensinam ao mesmo tempo, independente do nível de habilidades.

Há uma interessante fluidez no ambiente. Enquanto uns treinam, outros conversam, a comunidade agrega-se ao redor para vender seus produtos e alguns apenas observam. Com isso, pontua-se que a aprendizagem parte de um interesse do indivíduo, nutrido pelo incentivo coletivo. A liberdade em escolher qual técnica circense mais lhe agrada ou lhe é mais "fácil”, aliado à ausência de cobranças, contribui significativamente no sucesso do aprendizado.

\section{REFERÊNCIAS}

AGUIAR, A. R. C. CARRIERI, A. P. “Água de Lona” e "Sangue de Serragem” nos discursos de sujeitos circenses. Rev. O\&S. v. 23. n. 77. abr./jun. 2016, p. 247-262.

DUPRAT, Rodrigo Mallet. Realidades e particularidades da formacão profissional circense no Brasil: rumo a uma formacão técnica e superior. Tese (doutorado em Educação Física e Sociedade) - Universidade Estadual de Campinas. Campinas, 2014.

FIGUEIREDO, Carolina Machado de Senna. As Vozes do Circo Social. Dissertação (Mestrado em História) - Fundação Getúlio Vargas. Rio de Janeiro, 2007. Disponível em: http://bibliotecadigital.fgv.br/dspace/handle/10438/2097 
GARCIA, C. G. Cultura e Cidade: novas configurações socioespaciais na era pós-industrial. Anais: XVII ENAMPUR. São Paulo, 2017.

MINAYO, Maria Cecília de Souza (org.). Pesquisa social: teoria, método e criatividade. 29. ed. Petrópolis, RJ: Vozes, 2010.

RESENDE, José. Formação do artista no Brasil. In: Revista Malasartes. São Paulo, set./out./nov. 1975, p. 24-25.

WOODWARD, K. Identidade e diferença: uma construção teórica e conceitual. In: SILVA, T. T. HAAL, S. WOODWARD, K. (Org.) Identidade e diferença: a perspectiva dos estudos culturais. Petrópolis: Vozes, 2005. 